The Open Mechanical Engineering
Bentham open
CrossMark
Content list available at: www.benthamopen.com/TOMEJ/
DOI: $10.2174 / 1874155 \mathrm{X} 01610010000$

\title{
Retraction Notice: Control System Design for Feeding Machine of Sound Absorption Board Production Line
}

Yanjun Xiao ${ }^{*}$, He Zhang, Rui Liu, Yuxiang Liu and Yongcong Li

School of Mechanical Engineering HEBUT, Tianjin, 300130, China

\section{RETRACTION}

The Publisher and Editor have retracted this article [1] in accordance with good ethical practices. After thorough investigations we believe that the peer review process was compromised. The article was published online on 26-06-2015.

\section{REFERENCE}

[1] Y. Xiao, H. Zhang, R. Liu, Y. Liu, and Y. Li, "Control System Design for Feeding Machine of Sound Absorption Board Production Line", Open Mech. Eng. J., vol. 9, pp. 388-394, 2015.

(C) Xiao et al.; Licensee Bentham Open.

This is an open access article licensed under the terms of the Creative Commons Attribution-Non-Commercial 4.0 International Public License (CC BY-NC 4.0) (https://creativecommons.org/licenses/by-nc/4.0/legalcode), which permits unrestricted, non-commercial use, distribution and reproduction in any medium, provided the work is properly cited.

* Address correspondence to this author at the School of Mechanical Engineering, Hebei University of Technology, Tianjin, 300130, China; Tel: 13388007288; E-mail: x_yanjun2009@163.com 